\title{
MANUSIA DAN PEMAKNAAN RUANG KOTA DALAM ANTOLOGI CERPEN SALOME DAN ORANG-ORANG BALIKPAPAN
}

\section{HUMAN AND THE IMPORTANCE OF CITY SPACE IN THE ANTHOLOGY OF SALOME AND ORANG-ORANG BALIKPAPAN SHORT STORIES}

\author{
Diyan Kurniawati \\ Kantor Bahasa Kalimantan Timur \\ Jalan Batu Cermin Nomor 25, Sempaja Utara, Samarinda 75119 \\ Pos-el:kurniawati_diyan@yahoo.com
}

*) Naskah masuk: 23 Maret 2019. Penyunting: Abd. Rahman, S.S. Suntingan I: 25 April 2019. Suntingan II: 14 Mei 2019

\begin{abstract}
Abstrak
Tulisan ini membahas pemaknaan ruang kota bagi manusia yang tinggal di dalamnya dalam antologi Salome dan Orang-Orang Balikpapan. Dengan teori sosiologi sastra dan didukung dengan teori tentang ruang kota, penelitian ini menganalisis posisi manusia di ruang kota dan makna ruang kota bagi manusia yang tinggal di dalamya. Posisi manusia ditampilkan dalam berbagai kelas sosial ekonomi. Oleh karena itu, relasi antarmanusia dalam berbagai kelas sosial ekonomi juga akan dianalisis. Analisis menunjukkan perjalanan manusia mempertahankan eksistensi di ruang kota mempertemukan manusia pada manusia lain dengan berbagai latar sosial, ekonomi, dan budaya. Manusia yang bermigrasi di ruang kota menemukan perhatian dan empati dari manusia lain sehingga ia dapat menemukan keluarga dan rumah baru. Pertahanan eksistensi yang penuh dengan persaingan tetap dapat menyebabkan manusia lain berempati. Ruang kota tidak hanya dijadikan sebagai ajang jual beli, menuntut hak dan melakukan kewajiban, melainkan di ruang kota manusia tetap dapat berempati satu sama lain. Empati tidak harus berwujud materi. Perhatian mengenai perkembangan individu lain, terutama kanak-kanak, juga merupakan wujud empati yang sangat bermanfaat bagi manusia lain. Cerpen-cerpen dalam Salome dan Orang-Orang Balikpapan menunjukkan manusia di ruang kota yang mempertahankan nilai-nilai sosial di antara ketatnya persaingan dalam mempertahankan eksistensinya.
\end{abstract}

Kata Kunci: manusia, kota, eksistensi

\begin{abstract}
This paper discusses the importance of city space for humans who live in it in the anthology of Salome and Orang-Orang Balikpapan. It uses sociological theory of literature and a theory of urban space. This study analyzes the position of humans in urban space and the importance of urban space for humans who live in it. Human position is displayed in various socio-economic classes. Therefore, relations between people in those various socio-economic classes will also be analyzed. It shows that the journey of human beings maintaining their existence in the city space brings together humans to other humans with various social, economic, and cultural backgrounds. Humans who migrate to urban spaces find attention and empathy from the others so that they can find new family and homes. The defense of their existence that is full of competition can cause other humans to develop empathy. In
\end{abstract}


urban space, humans do not only buy and sale things, demand rights, and carry out obligations, but also can still show empathy to the others. Empathy demonstrated through attention to the development of others, especially children, is also a form of empathy that is very beneficial to the others. Short stories in Salome and Orang-Orang Balikpapan show humans in the urban space who maintain their social values in their intense competition maintaining their existence.

Keywords: human, city, existence

\section{PENDAHULUAN}

Ruang kota hingga saat ini menjadi salah satu tujuan manusia sebagai tempat untuk mempertahankan eksistensinya. Tercampurnya berbagai budaya sebagai akibat perpindahan manusia ke ruang kota diyakini menjadi salah satu penyebab persoalan yang timbul di ruang kota. Ruang kota yang keras karena penuh dengan persaingan juga menambah stigma negatif bagi tempat tersebut. Stigma negatif lainnya adalah gaya hidup individualistis yang menyebabkan keterasingan individu-individu di ruang kota. Dalam Kuntowijoyo (20086:114) diungkapkan bahwa kota-kota besar mulai menjadi metropolitan yang menyajikan bentuk masyarakat yang berbeda dengan pedesaan. Keramahan dan keakraban yang ditunjukkan oleh desa dan kota kecil telah digantikan dengan kekerasan dan keangkuhan kota. Hubungan individu di dalamnya menjadi hanya hubungan impersonal semata. Dengan demikian, ruang kota menimbulkan individu mengalami keterasingan.

Namun, pemaknaan kota tidak hanya sebatas menjadi tempat mempertahankan eksitensi manusia yang ada di dalamnya. Karena banyaknya manusia dari berbagai latar belakang sosial ekonomi dan budaya, ruang kota juga dapat menjadi tempat manusia untuk pengembangan peran sosialnya. Pemaknaan ruang kota tersebut ditunjukkan dalam antologi Salome dan Orang-Orang Balikpapan. Antologi ini diterbitkan dalam rangka memperingati ulang tahun ke-120 Kota Balikpapan. Pemaknaan kota (Balikpapan) dalam antologi tersebut menarik dan penting untuk diteliti lebih lanjut. Manusia dalam Salome dan Orang-Orang Balikpapapan mempunyai keterikatan dengan ruang kota (Balikpapan). Melalui berbagai posisi manusia di ruang kota tersebut akan diketahui makna ruang kota bagi manusia yang ada di dalamnya. Oleh karena itu, masalah dalam penelitian ini adalah bagaimana posisi manusia di ruang kota dan bagaimana pemaknaan ruang kota bagi manusia yang ada di dalamnya?

\section{TEORI}

Penelitian ini menggunakan teori sosiologi sastra dan didukung dengan teori tentang ruang kota. Dalam Wellek dan Warren (1993:110) diungkapkan bahwa pendekatan sosiologi sastra tidak hanya mempelajari kaitan sastra dengan masyarakat, tetapi juga memberi batasan bagaimana seharusnya hubungan itu dalam masyarakat di zaman sekarang dan masa datang. Damono (2002:1) mengungkapkan bahwa sastra tidak dapat dipisahkan dari dari kehidupan masyarakat. Di dalam sastra terdapat hubungan antara sastrawan, masyarakat, dan sastra. Sementara itu, kehidupan adalah suatu kenyataan sosial. Oleh karena itu, antara sastrawan, sastra, dan masyarakat terdapat hubungan yang tidak dapat dipisahkan. Ian Watt (dalam Damono, 2002:4-5) juga menyebutkan bahwa sastra menampilkan fakta-fakta sosial di masyarakat. Karya sastra berusaha menampilkan keadaan masyarakat secermat-cermatnya. Swingewood (dalam Faruk, 1994:1) menjelaskan bahwa sosiologi sebagai studi yang ilmiah dan objektif me- 
ngenai manusia dalam masyarakat, studi mengenai lembaga-lembaga dan prosesproses sosial. Goldmann (dalam Faruk, 2012:90) menjelaskan bahwa karya sastra sebagai fakta kemanusiaan merupakan struktur yang berarti. Hal ini berarti penciptaan karya sastra adalah untuk mengembangkan hubungan manusia dan dunia. Sementara itu, Escarpit (2005:3) menjelaskan bahwa semua fakta sastra menyiratkan adanya penulis, buku, dan pembaca atau secara umum dikatakan sebagai pencipta, karya, dan publik.

Massey dan Nzegwa (dalam Barker, 2013:314) menjelaskan ruang ialah konstruksi dan materialisasi sosial yang mengungkapkan asumsi dan praktik kultural. Ruang merupakan unsur utama untuk memahami bertahannya sistem kapitalisme yang terus dapat bermetamorfosis ke dalam berbagai bentuk. Sementara itu, terdapat berbagai pandangan mengenai ruang kota. Weber (dalam Barker, 2013:314) menjelaskan bahwa kehidupan kota penopang demokrasi industri modern sekaligus menjelaskan rasio instrumental dan kerangkeng besi organisasi birokrasi. Di sisi lain, Marx (dalam Barker, 2013:314) menjelaskan bahwa kota sebagai tanda kemajuan dan lompatan besar produktivitas yang ditimbulkan oleh kapitalisme. Sementara itu, di sisi lain Marx menjelaskan bahwa kota merupakan tempat bagi kemiskinan dan kekejian. Simmel (dalam Barker, 2013:314) menjelaskan bahwa kota ialah tempat lahirnya estetika modernisme dan tempat bagi pelarian dari kontrol tradisi. Durkeim (dalam Barker, 2013:314) berharap kehidupan kota akan menjadi ruang kreativitas, kemajuan, dan tatanan moral baru, tetapi ia menjelaskan kekahwatirannya bahwa kota akan menjadi arena bagi kebusukan moral. Wirth (dalam Barker, 2013:315) menjelaskan bahwa kehidupan kota didasarkan pada adanya sejumlah besar orang yang hidup berdekatan tanpa benar-benar mengenal satu sama lain sehingga mengharuskan mereka menjalankan transaksi instrumental dan mengabaikan pertemuan di antara mereka. Hal ini mengarah pada hubungan yang superfisial, transitif, dan kompetitif dan perasaan terasing dan tidak berdaya. Penghuni kota membentuk asosiasi satu sama lain yang didasarkan pada gaya hidup dan kebudayaan. Barker (2013:329) mengatakan bahwa bagi mereka yang berada dalam posisi menikmati, kota menawarkan kesempatan kerja dan hiburan, percampuran dan pertemuan dengan berbagai orang dan kebudayaan, daya tarik, ketidakpastian, dan kejutan-kejutan yang akan muncul. Teori sosiologi sastra dalam penelitian ini akan diterapkan melalui analisis mengenai posisi manusia yang berada di ruang kota dan makna ruang kota bagi manusia yang hidup di dalamnya.

\section{METODE}

Penelitian ini menggunakan metode kualitatif dan teknik deskriptif analitik yang didukung oleh teori sosiologi sastra. Huberman dan Miles (dalam Denzin dan Lincoln, 1994: 428) menyebutkan bahwa metode kualitatif menggunakan proses manajemen data dan metode analisis. Huberman dan Miles juga menyatakan bahwa manajemen data secara pragmatik dalam pengoperasiannya memerlukan sebuah sistem, koherensi proses pengumpulan data, pengarsipan data, dan penelusuran ulang datadata. Analisis data mengandung tiga subproses, yaitu reduksi data, tampilan data, dan verifikasi data.

Sementara itu, menurut Ratna (2008: $46-47)$, metode kualitatif memanfaatkan cara-cara penafsiran dengan menyajikannya dalam bentuk deskripsi. Sumber data penelitian kualitatif dalam ilmu sastra adalah karya, naskah, dan data penelitiannya. Data 
formalnya adalah kata-kata, kalimat, dan wacana.

Adapun teknik deskriptif analitik adalah metode yang dilakukan dengan cara mendeskripsikan fakta-fakta kemudian disusul dengan analisis (Ratna, 2006: 53). Oleh karena itu, penelitian ini dilakukan dengan langkah-langkah sebagai berikut.

1. Menentukan data primer, yaitu cerpencerpen dalam antologi Salome dan Orang-Orang Balikpapan yang berjudul "Terusir" karya Ali Ahmad, "Mba Rum" karya Camila Ajeng, dan "Cahaya Pasar" karya Rinne Agustien.

2. Mendeskripsikan dan menganalisis posisi manusia dalam ruang kota. Relasi antarindividu dan persoalan-persoalan yang menyertainya juga akan dianalisis.

3. Mendeskripsikan dan menganalisis makna kota bagi manusia yang bertempat tinggal di dalamnya. Dengan demikian akan diketahui pemaknaan ruang kota bagi manusia yang ada di dalamnya.

\section{PEMBAHASAN}

\section{Posisi Manusia di Ruang Kota}

Manusia di ruang kota ditampilkan dalam cerpen "Terusir" karya Ali Ahmad. Cerpen tersebut menampilkan tokoh utama Aku yang bermigrasi ke kota Balikpapan. Migrasi ke kota Balikpapan disebabkan karena tokoh Aku ditempatkan bekerja di tempat tersebut. Secara sosial ekonomi tokoh Aku ditampilkan sebagai individu yang berpendidikan. Hal tersebut ditunjukkan budaya baca yang ia lakukan pada saat ia menunggu pesawat.

Sambil menunggu panggilan ke pesawat yang sekiranya masih dua puluh menit lagi itu, kuhabiskan waktuku untuk membaca sebuah buku, walaupun tiap kata yang kubaca di halaman buku itu justru membuat otakku sibuk menyemburkan gelembung-gelembung memori yang siap menampilkan adegan apa saja. Seperti roll film (Ahmad dalam Rachman, 2017:24)

Tokoh Aku juga ditampilkan sebagai individu yang mapan secara sosial ekonomi. Hal tersebut ditunjukkan melalui pekerjaan yang dijalaninya. Tokoh Aku bekerja sebagai peneliti dan pengawas drainase kota dan pembangunan di kota-kota di Indonesia.

Aku sedang mengikuti program kantor yang mengharuskan untuk berpindahpindah kantor cabang untuk meneliti dan mengawasi sistem drainase kota dan pembangunan di masing-masing proyek di seluruh wilayah di Indonesia, dan kota pertamaku kala itu adalah Balikpapan, sekaligus kota terlamaku karena aku tinggal di sini hingga dua tahun (Ahmad dalam Rachman, 2017:25).

Pekerjaan sebagai peneliti dan pengawas menunjukkan pekerjaan tokoh Aku yang baik secara sosial dan ekonomi. Kemapanan secara sosial ekonomi di ruang kota tokoh Aku juga ditampilkan melalui fasilitas kendaraan yang dipunyai si Aku. Pada saat ia mengadakan perjalanan dinas dari Balikpapan ke Samarinda ia turun dari mobilnya untuk menolong orang lain yang mobilnya mogok di tengah jalan.

Waktu itu aku sadar bahwa jiwaku masih sangat polos dan agak-agak gampang dibodohi sehingga aku memutuskan untuk turun dari mobilku saat ada wanita berdiri hujan-hujanan seperti minta pertolongan itu, aku tahu kalau bertemu orang lain mungkin aku sudah dimakimaki karena sangat bodoh turun dari mobil di tengah hutan begitu,,, (Ahmad dalam Rachman, 2017:25). 
Kutipan tersebut menunjukkan tokoh Aku telah mapan secara sosial ekonomi karena pekerjaan yang telah dipunyainya. Hal tersebut juga ditampilkan tetap tinggal di tempat kos yang memerlukan biaya banyak meskipun tokoh Mamak menawarinya tempat tinggal.

Rumah Mamak ini besar, tinggallah di sini saja, tidak usah nge-kos, sayang uangnya," ujar Mamak dengan idenya yang kadang-kadang membuatku tertohok.

"Maafkan Mamak ya, bicaranya suka ngasal," katanya saat melepasku keluar rumah setelah aku pamit untuk pulang ke rumah kosku,.... (Ahmad dalam Rachman, 2017:26-17)

Kutipan tersebut menunjukkan posisi tokoh Aku di ruang kota secara ekonomi telah baik. Posisi tokoh Aku di ruang kota dalam "Terusir" ditampilkan sebagai orang yang berpendidikan dan mempunyai pekerjaan yang baik. Dengan demikian secara sosial ekonomi tokoh Aku ditampilkan sebagai individu yang mapan secara sosial ekonomi.

Dalam cerpen "Rum" ditampilkan tokoh Aku yang mengenal tokoh Rum. Tokoh Rum merupakan individu di ruang kota yang bermigrasi ke Balikpapan. Tokoh Rum bermigrasi ke Balikpapan untuk mencari peruntungan. Setelah berbagai usaha dilakukannya, ia akhirnya menjadi pemijat,

Yang aku tahu tentang Mba Rum hanya sedikit. Anaknya lima orang dan sudah dewasa semua, cucunya tiga orang, suaminya tidak bekerja,.... Suaminya dulu dapat tawaran pekerjaan borongan sebagai mandor buruh bangunan. Sekarang, karena sudah kurang yang memakai jasanya, dia menganggur. Mbak Rum yang punya keahlian memijatlah yang gantiin jadi sumber dana hidup di rumahnya.
“Waktu pertama turun kapal di pelabuhan, kukira Balikpapan itu hutan semua, dek," katanya suatu di sela-sela memijatku (Ajeng dalam Rachman, 2017:63).

Kutipan tersebut menunjukkan posisi tokoh Rum di ruang kota. Tokoh Rum berada dalam posisi sosial ekonomi yang rendah. Migrasi ke ruang kota merupakan usahanya untuk mempertahankan eksistensi. Di ruang keluarga tokoh Rum ditampilkan sebagai satu-satunya orang yang mempunyai sumber dana untuk menghidupi keluarganya. Pertahanan eksistensi di ruang kota ditampilkan melalui beberapa pekerjaan dan kejadian yang dilalui Rum. Ia juga mempunyai salon warisan temannya. Kebakaran yang pernah menimpa salonnya dan ketahanannya untuk tetap membuka salon merupakan bukti bahwa tokoh Rum mampu mempertahankan eksistensinya di ruang kota.

Saingannya banyak di situ, dek. Kan salon semua rata-rata," katanya suatu hari saat kutanya bagaimana usaha salonnya....

“Salon Mbak Rum gimana?” tanyaku.

“Terbakar bagian belakangnya, dek. Tapi depannya ndak apa-apa. Alat salon, ya, sebagian ikut terbakar (Ajeng dalam Rachman, 2017:64)

Kutipan tersebut menunjukkan tokoh Rum yang tetap berpikiran positif meskipun kerugian telah menimpa usahanya. Hal tersebut membuktikan bahwa tokoh Rum tetap ingin mempertahankan eksistensinya di ruang kota. Posisi yang rendah secara sosial ekonomi tidak membuatnya berpikir untuk menutup usahanya.

Sementara itu, dalam "Cahaya Pasar" karya Rinne Agustien ditampilkan melalui tokoh Aku yang berada di ruang kota. Tokoh 
Aku dan keluarganya ditampilkan sebagai manusia yang berada dalam sosial ekonomi yang rendah. Hal itu ditunjukkan melalui ayah tokoh Aku yang hanya dapat membuka kios di bagian belakang pasar. Keadaan ekonomi yang rendah ditunjukkan pula melalui keadaan keuangan keluarga tokoh Aku yang sangat minim untuk memenuhi keperluan sehari-hari dan tempat tinggal yang tidak layak.

... Ayah hanya sanggup menyewa kios belakang. Uang tabungan sudah dipakai untuk pengobatan ibu. ... Namun sekarang untuk bisa makan sampai besok saja sudah bersyukur.... (Agustine dalam Rachman, 2017:183184)

Rumahku hanyalah rumah kayu berdinding triplek. Sekolah pun itu karena kebaikan hati pak walikota yang menggratiskan biaya sekolahku hingga SMA (Agustine dalam Rachman, 2017:188).

Kutipan tersebut menunjukkan posisi manusia yang berada pada tingkat sosial ekonomi yang rendah di ruang kota. Akan tetapi, pendidikan dalam keluarga tokoh Aku tetap diprioritaskan. Dengan biaya pemerintah setempat, tokoh Aku dapat bersekolah.

Keadaan keluarga tokoh Aku yang secara tingkat sosial ekonomi rendah, membuat tokoh Aku memosisikan diri secara rendah pula. Hal itu ditunjukkan pada saat seseorang menemukan bakat menggambarnya. Tokoh Aku memosisikan dirinya secara rendah dan tidak layak menerima hal yang lebih baik.

Menurut Tante Husna, bakatku ini harus dikembangkan. Aku sendiri tidak pernah memimpikan untuk belajar lebih jauh mengenai menggambar komik. Aku tahu diri, aku anak piatu yang ikut bapak kerja di pasar Klandasan (Agustine dalam Rachman, 2017:188).

Kutipan tersebut menunjukkan individu yang memosisikan diri secara rendah. Hal tersebut disebabkan keadaan sosial ekonominya yang rendah. Ia merasa tidak mungkin memimpikan suatu hal yang lebih baik daripada yang diterimanya sekarang.

\section{Makna Ruang Kota}

Dalam cerpen "Terusir" ruang kota ditampilkan sebagai tempat yang kuat dengan dirinya. Meskipun ruang kota (Balikpapan) merupakan tempat migrasinya, tokoh Aku telah menganggap kota tersebut sebagai rumahnya, tempatnya kembali. Pada awal perpindahannya di Balikpapan, tokoh Aku telah mempunyai orang-orang yang menganggap dan dianggapnya keluarga. Tokoh Mamak dan keluarganya yang ditolong pada saat mobilnya mogok menganggap tokoh Aku sebagai keluarganya.

"Rumah Mamak ini besar, tinggallah di sini saja, tidak usah nge-kos, sayang uangnya," ujar Mamak dengan idenya yang kadang-kadang membuatku tertohok.

“Bagiku kota itu adalah Balikpapan. Bukan hanya jatuh cinta dan selalu membuat rindu, di atas semua itu. Bagiku Balikpapan adalah rumah (Ahmad dalam Rachman, 2017:23-24).

Penawaran tokoh Mamak supaya tokoh Aku tinggal di rumahnya menunjukkan bahwa tokoh Aku di ruang kota telah mempunyai keluarga baru di Balikpapan. Selain itu, kota tersebut juga menampilkan tokoh Aku yang mempunyai teman, anak tokoh Mamak, yang sangat akrab dengan dirinya. Pada akhir pekan mereka mempunyai rutinitas kegiatan sendiri. Dari rutinitas tersebut tokoh $\mathrm{Aku}$ mengenal Balikpapan secara lebih rinci. 
Aku selalu menikmat momen-momen kebersamaan itu, yang kami sebut sebagai "ritual akhir-pekan". Aku menikmati ketika berlari pagi dengannya sambil menghirup udara segar di sepanjang Jalan Minyak yang kanan kirinya masih berupa hutan kota yang dipelihara oleh pemerintah setempat.... Aku menyukai idenya untuk menghabiskan malam minggu, mencoba-coba entah pisang pisang keju atau roti maryam dari kafe satu ke yang lainnya di deretan Ruko Bandar yang seluruh kafenya berada di atas air. ... Dengan dirinya, aku mengenal Balikpapan dari sudut yang berbeda... (Ahmad dalam Rachman, 2017:23-24).

Hal tersebut menunjukkan pemaknaan ruang kota (Balikpapan) bagi tokoh Aku. Ruang kota (Balikpapan) dimaknai sebagai rumah. Sebagai rumah, tokoh Aku selalu ingin datang ke Balikpapan. Keluarga yang menerima membuatnya mengetahui tempat-tempat di Balikpapan dan menjadikannya sebagai rumah tempat tokoh Aku pulang.

Dalam cerpen "Mbak Rum" pemaknaan ruang kota ditampilkan melalui tokoh Aku. Tokoh Aku mengenal Mbak Rum sebagai pemijat. Sebagai pelanggan pemijat Mbak Rum, tokoh Aku mengetahui sisi-sisi lain tokoh Rum. Cerita-cerita Mbak Rum ditanggapi oleh tokoh Aku.

"Aku ada dengar soal kebakaran di daerah itu, Mbak. Tapi aku gak tahu kalau salon Mbak Rum ikutan kena juga."...

"Aku juga dengar sih kalau itu, Mba. Emang banyak banget, ya?"

"Wuiiih, banyak betul, dek. Di bagian depan salon, tapi bagian belakang dijadiin tempat begituan. Ngeri juga kan kalau cari duit kalau sudah gitu caranya."
Aku hanya bisa mengernyitkan alis mendengar curhatnya. (Ajeng dalam Rachman, 2017:65).

Kutipan tersebut menunjukkan tokoh Aku memperhatikan sisi kemanusiaan tokoh Aku. Tokoh Aku tidak semata-mata hanya mementingkan kepentingannya, tetapi ia berusaha mengetahui latar belakang Mbak Rum di kota tersebut.

Tokoh Aku juga menanggapi pada saat Mbak Rum bercerita mengenai anaknya yang mengalami gangguan jiwa setelah belajar ilmu kebatinan di kota lain. Anaknya sempat hilang di hutan pada saat bersama temannya naik motor. Ia juga sempat akan bunuh diri. tahu....

“Terus?" tak sabar rasanya ingin

“Terus ketemua, Mba?"

"Tiga hari ndak mau ngomong dia. Sampai kucarikan orang pintar, baru ngomong dia. Bilangnya, dia ngikutin kupu-kupu kuning sampai ke kampung di dalam hutan situ....

“Wuiiih....," takjubku, sambil kuhayalkan kampung gaib macam apa di tengah hutan di situ (Diajeng dalam Rachman, 2017:67).

Kutipan tersebut menunjukkan pemaknaan ruang kota yang ditampilkan melalui tokoh Aku. Tokoh Aku ingin mengetahui keluarga tokoh Rum. Keingintahuan tokoh Aku mengenai anak tokoh Rum yang hilang merupakan bentuk kepedulian tokoh Aku terhadap Rum yang berprofesi sebagai pemijat. Bentuk kepedulian tokoh Aku terhadap tokoh Rumjuga ditampilkan melalui tawaran teh hangat kepada tokoh Rum. Tokoh Aku tetap ingin mengetahui keluarga tokoh Rum.

Aku masih ingin mendengar ceritanya, jadi kutawarkan teh hangat padanya 
alih-alih minta dipijat. Dia mengiyakan tawaranku (Diajeng dalam Rachman, 2017:67).

Kepedulian tokoh Aku juga ditampilkan melalui kepedulian tokoh Aku pada saat tokoh Rum membiarkan pemijatnya itu tertidur sebelum memijatnya.

Beberapa menit setelahnya ketika aku kembali, Mba Rum malah tertidur di kasur yang tadinya diperuntukkan memijatku. Aku tak tega membangunkannya, jadi kuletakkan saja teh hangat yang barusan kubuat ini di meja dekat situ. Biarlah dia tidur. Badan pegalku bisa menunggu kapan-kapan, tapi lelah pikirannya harus diistirahatkan malam ini (Diajeng dalam Rachman, 2017:67— 68).

Kutipan tersebut menunjukkan pemaknaan ruang kota tidak hanya sekadar untung dan rugi. Melalui tokoh Aku ditunjukkan bahwa di ruang kota manusia mampu berpikir mengenai kepedulian terhadap manusia lain. Tokoh Aku tidak menuntut tokoh Rum untuk melakukan kewajibannya (memijat). Ia membiarkan tokoh Rum untuk beristirahat tanpa ada gangguan. Cerpen "Mba Rum" menunjukkan ruang kota merupakan tempat manusia untuk mengetahui sisi-sisi kemanusiaan secara lebih detail.

Cerpen "Cahaya Pasar" juga menampilkan makna ruang kota (Balikpapan) bagi manusia yang tinggal di dalamnya. Cerpen tersebut menampilkan tokoh Aku yang selalu mengikuti ayahnya berjualan di pasar Klandasan. Keikutsertaannya tersebut membuatnya mengenal banyak orang di sekitar pasar.

Sepulang sekolah aku selalu melewati kedai kopi itu. Pemiliknya bernama Om Rama, aku berkenalan dengannya.... Selang beberapa bulan, dua perempuan cantik berkerudung membuka kios buku tepat di sebelah kedai kopinya Om Rama. Namanya Tante Husna dan Tante Lia.... Om Bimbim adalah temannya Om Rama yang bekerja di kedai kopi. ... Mereka semua baik kepadaku dan temantemanku (Agustine dalam Rachman, 2017:186-187).

Hal itu menunjukkan tokoh Aku menikmati suasana di pasar. Keikutsertaannya di pasar bersama ayahnya di pasar tidak membuat Aku rendah diri. Ia justru mempunyai banyak teman.

Selain mengenal banyak orang, lingkungan pasar juga membuat tokoh Aku mengenal situasi menyenangkan. Dengan adanya kios buku di pasar, ia dan temantemannya mendapat kesempatan hadir dalam acara dongeng. Mereka juga rajin membaca buku-buku di kios tersebut, Tokoh Aku juga tertarik menggambar setelah mengenal tokoh Om Bimbim yang gemar menggambar.

... Esoknya aku hadir bersama teman-teman yang berjumlah 10 orang. Kami duduk manis mendengar cerita yang dibawakan Kak Fanni dan Kak Nina. ... Semenjak itu, aku dan temanteman menjadi pengunjung terajin datamg ke kios pena dan buku.... (Agustine dalam Rachman, 2017:185).

Om Bimbim ini jago sekali menggambar. Aku suka melihatnya menggambar, kemudian menirukannya.... Seiring waktu aku bisa menggambar burung hantuku sendiri. Om Bimbim dan Om Rama yang mengajariku (Agustine dalam Rachman, 2017:186-187)

Hal tesebut menunjukkan makna pasar secara positif. Dalam pasar individu tidak hanya berinteraksi jual beli, tetapi dapat melebihi hal tersebut. Pasar dapat membuat tokoh Aku bersosialisasi secara menyenang- 
kan. Wawasan di luar sekolah ia dapatkan melalui kios buku yang berada di pasar.

Pasar juga mengantarkan individu mengenal dunia menggambar. Menggambarlah yang kemudian mengantarkan tokoh Aku menjadi seorang pembuat komik dan mendapat kesempatan belajar di Jepang. Bantuan dari orang-orang yang dikenalnya di pasar menunjukkan bahwa pasar menjadi sebuah tempat yang sangat bermakna.

Aku semakin heran denganjawaban Ayah. Om Rama memanggilku lalu memelukku dan berkata kamu akan meneruskan belajar membuat komik di Jepang.

Merekalah yang selama ini mengunggah cerita komikku ke media sosial, membuatkan akun Instagram cerita komikku hingga membuatkan Web atas namaku. Sungguh aku tidak tahu sama sekali (Agustine dalam Rachman, 2017:189)

Hal tersebut menunjukkan makna ruang kota, yaitu pasar, sebagai tempat bersosialisasi dan berempati antarindividu di dalamnya. Perkenalan antarinvidu dalam pasar tidak membuat mereka bersaing secara negatif satu sama lain. Akan tetapi, mereka berempati terhadap keberlangsungan pendidikan individu lain. Ruang kota (Balikpapan), terutama pasar, bagi tokoh Aku dimaknai sebagai tempat penting bagi dirinya. Orang-orang di dalamnya adalah keluarga yang mempunyai andil yang sangat besar bagi perkembangan dirinya.

Setelah sepuluh tahun aku tinggal di Jepang, aku kembali ke Balikpapan. Tujuan pertamaku adalah kedai kopi sahabat dan kios pena dan buku di pasar Klandasan. Bertemu mereka, keluarga yang sengaja diberikan Tuhan kepadaku.... (Agustine dalam Rachman, 2017:189)
Hal tersebut menunjukkan makna positif ruang kota, yaitu pasar Klandasan. Ruang kota (Balikpapan), terutama pasar Klandasan, merupakan tempat kembalinya individu setelah belajar ke luar negeri. Pasar tersebut dimaknai sebagai rumah yang di dalamnya dipenuhi keluarga yang mempunyai perhatian dan empati terhadap individu lain.

\section{PENUTUP}

Analisis mengenai cerpen "Terusir", "Mba Rum", "Cahaya Pasar" dalam Salome dan Orang-Orang Balikpapan menunjukkan makna ruang kota, yaitu Balikpapan, bagi manusia yang tinggal di dalamnya. Ruang kota menjadi tempat manusia mempertahankan eksistensi dengan penuh persaingan. Namun, ruang kota juga mempunyai sisi-sisi positif yang dirasakan oleh manusia yang tinggal di dalamnya.

Perjalanan mempertahankan eksistensi di ruang kota mempertemukan manusia pada manusia lain dengan berbagai latar sosial, ekonomi, dan budaya. Relasi kemanusiaan ditunjukkan melalui manusia yang menemukan keluarga baru di ruang kota tempatnya bermigrasi. Manusia yang bermigrasi di ruang kota menemukan perhatian dan empati dari manusia lain sehingga ia dapat menemukan keluarga dan rumah baru. Pertahanan eksistensi yang penuh dengan persaingan dapat menyebabkan manusia lain berempati. Ruang kota tidak hanya dijadikan sebagai ajang jual beli atau menuntut hak dan melakukan kewajiban. Akan tetapi, manusia di ruang kota tetap dapat mewujudkan perhatian dan empati bagi manusia lain. Empati tidak harus selalu berwujud materi. Perhatian mengenai perkembangan individu lain, terutama kanakkanak, juga merupakan wujud empati yang sangat bermanfaat bagi manusia lain.

Kelas-kelas sosial ekonomi tidak lagi menjadi penghalang manusia di ruang kota 
untuk saling berhubungan secara sosial. Sulitnya mempertahankan eksistensi di ruang kota tidak menjadikan manusia kehilangan sisi-sisi kemanusiannya. Cerpencerpen dalam Salome dan Orang-Orang Balikpapan menunjukkan manusia di ruang kota yang mempertahankan nilai-nilai sosial di antara persaingan hidup yang keras.

\section{DAFTAR PUSTAKA}

Barker, Chris. 2013. Cultural Studies, Teori dan Praktik. Terj. oleh Nurhadi. Yogyakarta: Kreasi Wacana.

Damono, Sapardi Djoko Damono. Pedoman Penelitian Sosiologi Sastra. Jakarta: Pusat Bahasa, Departemen Pendidikan Nasional.

Denzin, Norman K, dan Yvonna S. Lincoln (ed.). 1994. Handbook of Qualitative Research. California: Sage Publications.
Escarpit, Robert. 2005. Sosiologi Sastra. Terj. oleh Ida Sundari Husein. Jakarta: Yayasan Obor Indonesia.

Faruk. 1994. Pengantar Sosiologi Sastra. Yogyakarta: Pustaka Pelajar.

- - - , 2012. Metode Penelitian Sastra, Sebuah Penjelajahan Awal. Yogyakarta: Pustaka Pelajar.

Kuntowijoyo. 2006. Budaya dan Masyarakat. Yogyakarta: Tiara Wacana.

Rachman, Arif Er. 2017. Salome dan OrangOrang Balikpapan. Balikpapan: Nulis Buku Club Balikpapan dan Rimedia Pustaka.

Ratna, Nyoman Kutha. 2006. Teori, Metode, dan Teknik Penelitian Sastra. Yogyakarta: Pustaka Pelajar.

Wellek, Rene, dan Austin Warren. 1993. Teori Kesusastraan. Terj. Melani Budianta. Jakarta: Gramedia. 